\title{
Touch as social control: Haptic organization of attention in adult-child interactions
}

\author{
Asta Cekaite \\ Linköping University Post Print
}

Tweet

N.B.: When citing this work, cite the original article.

Original Publication:

Asta Cekaite, Touch as social control: Haptic organization of attention in adult-child interactions, 2016, Journal of Pragmatics, (92), 30-42.

http://dx.doi.org/10.1016/j.pragma.2015.11.003

Copyright: Elsevier

$\underline{\text { http://www.elsevier.com/ }}$

Postprint available at: Linköping University Electronic Press

http://urn.kb.se/resolve?urn=urn:nbn:se:liu:diva-126144

(9) $(1) \Theta(\Theta \mathrm{XY}$ 


\title{
Touch as social control: Haptic organization of attention in adult-
}

\author{
child interactions
}

\section{Introduction}

Touch plays an important role in human interaction, including areas such as achieving another person's compliance and displaying status, intimacy, and affection. As a sensory/communicative modality it has, thus far, largely been the focus of psychological studies measuring, for instance, the effects of interpersonal touch on infant development, social power, solidarity and compliance (Hertenstein \& Weiss, 2011). Such studies have examined the forms and functions of touch (usually in laboratory environments), suggesting that the communicative potentials of touch are contextualized by the multimodal, interactional situation. Interactional studies have only recently engaged in an investigation of the 'when', 'why' and 'how' of touch, demonstrating the interactional organization and socializing potentials of haptic actions (Burdelski, 2010; Cekaite, 2010; Tulbert \& Goodwin, 2011; Käntää \& Piirainen-Marsh, 2013; Moore, 2013).

Taking its starting point in an interactional perspective, the present study focuses on a significant yet under-researched area, namely, the ties between touch and social control. The study examines the interactional organization of control touch used in adult-child interactions (in primary school settings for 7-year-olds and in families in Sweden). Control touches are defined here as haptic acts that are used to control another person's behavior. More specifically, the focus in on temporally sustained, physically light adult-child touch that is used to manage the recipient's body to achieve compliance and to monitor the child's embodied actions in the (evolving) participation frameworks (e.g., re-directing another person's attention or altering his/her behavior). It is argued that an examination of embodied practices can provide concrete insights into the mundane corporeal features of social 
interaction and outline some of the 'body techniques' (Mauss, 1973) relevant to inculcating socially and physically accountable ways of acting in everyday interactions.

\section{Theoretical perspective and prior research on touch}

Theoretically, the present study adopts the view that intersubjectivity is material and embodied: Moving bodies experience, resonate with, initiate and constrain the actions and movements of other bodies by deploying a full range of semiotic resources, tools, and modalities available within a shared sensory and corporeal space (cf. Merleau-Ponty, 1962; Csordas, 1998; Goodwin, 2000; Streeck et al., 2011). Coordination of interaction, in addition to talk, is linked to the apperception of the movement (or the stability of other bodies) on the basis of one’s own kinesthetic experiences (Sheets-Johnstone, 2011: 29).

Touch, as a communicative/sensory mode, is fundamentally characterized as an 'immediacy behavior' (Montagu, 1971). The communicative potentials of touch are commonly bidirectional and contingent and touching or letting someone else touch one can escalate the balance of intimacy (Linell, 2009). Prior research has shown that particular aspects of touch, such as its form and duration, can influence how it is interpreted and that 'the perceptions and interpretations of nonverbal behaviors' are located in the context in which they occur (Herteinstein \& Weiss, 2011; Fleck \& Chavajay, 2009: 284). Some studies have suggested, for instance, the prevalence of coordination of talk and various types of touch (Yarborough \& Jones, 1985).

Recent interactional studies have brought attention to touch in social interaction, demonstrating that touch behaviors can be organized as orderly patterns of corporeal actions (Goodwin, In press). Studies taking an anthropological perspective have revealed the deployment of multisensory (touch, smell, gaze) resources in adult-child (socializing) interactions (de León, 1998; Ochs, Salomon \& Sterponi, 2005; Goodwin, 2006). Ethnographic 
evidence based on a micro-analysis of interaction shows that control touch in adult-child directives is deployed to construct and negotiate the frameworks of co-orientation and compliance, initiating and at times enforcing the accomplishment of the requested action. 'Shepherding' control touch enforces the child's locomotion, reconfiguring the alignment of bodies vis-à-vis each other: Adult speakers can reposition the body of a child recipient toward the target activity, steering or carrying the child toward the final destination (Cekaite, 2010; 2012; Goodwin \& Cekaite, 2013). Forceful touch is used for disciplining the child's bodily actions, as in staging, organizing and enforcing a time-out (McIlvenny, 2009).

Touch as a corporeal form of behavior is thus embedded in and linked to the social and cultural context, and constitutes some of the 'body techniques,' i.e., methods used to monitor and impose specific bodily action patterns (Mauss, 1973). Appropriate bodily participation, i.e., children's morally relevant embodied gender conduct, is shaped and corrected through haptic prompts and instructions (Burdelski, 2010). Touch is also used to organize multimodal participation frameworks and calibrate children’s attention, shaping pre-verbal and verbally developing children’s interactional participation (de León, 1998; 2012; Ochs et al., 2005) and older children’s accomplishment and orientation to routine tasks (Goodwin, 2006; Tulbert \& Goodwin, 2011). While these studies have investigated touch that manages the child's bodily actions by bringing the body into motion (and enforcing movement), the uses of temporally extended, passive forms of touch in adult-child interactions, when taking control of and establishing the child's attention, have thus far been less explored.

\section{Socialization of attention and participation}

Joint attention and mutual orientation constitute some of the pre-requisites for coordinated action and sociality (Goodwin, 2007) and the '[p]articipation framework, sustained through joint attention, is a basic analytic unit of socialization and learning’ (de León 2012: 104). 
Joint attention is thus 'fundamentally an interactional process inseparable from the flow of social activity’ (Brown, 2012: 35). A number of ethnographic studies have examined children's attention when it is aimed at persons, social actions and activities, rather than looking at very young children's attention to objects (e.g., toys), as in much of the psychological research conducted in laboratories (Tomasello \& Farrow, 1986). These studies demonstrate that attention is acquired and deployed by young children from early on and is linked to socialization and 'attention-organizing behaviors' (de León, 2012; Tulbert \& Goodwin, 2011).

Participation and involvement in situation ('actions demonstrating forms of involvement performed by parties', Goodwin \& Goodwin, 2004: 222) are guided by situational requirements that are of a moral character (Goffman, 1963: 240), and according to Goffman's theoretical view, '[l]imits are put on those kinds of emigration of the self which can occur without leaving one’s physical position' (Goffman, 1963: 194). In concrete terms, participation in social interaction, for instance, hinges on the establishment and maintenance of interactional space, i.e., various spatial-orientational arrangements for sustaining a common orientational perspective, such as the F-formation (facing formation) (Kendon, 1990), where participants coordinate their actions around a single cognitive focus of attention (Goffman, 1963). The establishment of interactional space (Mondada, 2009; see also Broth \& Mondada, 2013) is dependent on the coordination between 'bodies-in-motion' (Merleau-Ponty, 1962). In this study, the understanding of body-in-motion extends beyond locomotion to incorporate shifts in participants' body posture, orientation, gaze, and gestures. Moreover, it suggests that touch (especially control touch), as corporeal, sensory co-presence, is significant in relation to kinesthesia, i.e., the ability of the body to agentively feel its movements (Cekaite, 2015). Bodily imposition and power-infused aspects of social actions can thereby be related to the bodily impact of touch in regard to the recipient's kinesthetic experiences. 
The present article focuses on a particular type of control touch behavior that is deployed in adult-child interactions in educational and family settings. The analysis explores temporally extended/sustained light forms of adult-child touch, and by examining the contextual configurations accompanying such forms of touch, the study outlines their interactional organization and functions. In addition to broadening our understanding of the multimodal features of social interactions, close interactional analysis of control touch in adult-child interactions, as suggested, can provide insights into 'how culture and social practices elaborate and shape the human body' (Turner, 2008: 48), because such touch is used to monitor and shape the child's attention towards persons, social actions, and activities.

\section{Method}

\subsection{Data and setting}

The data include two datasets: a video-ethnography of family life in Swedish middle-class families (eight families, 5- to 9-year-old boys and girls) and a video-ethnography of Swedish elementary school classroom interactions (7- to 8-year-old boys and girls, five female

teachers $)^{1}$. Video-recorded data (10 hours from each data set) have been analyzed to identify adults' control touches directed at children. ${ }^{2}$ They were identified from video-recordings using i) real-time and ii) slow-motion microanalysis, by marking the form of touch, its location, intensity and duration.

The present analysis focuses on a particular category of recurrent haptic control acts, i.e., temporally extended touches that involve sustained physical contact, when a person puts a hand or both hands on another person's hand, arm or shoulder, trunk, holds a person's arm, (non-forcefully) sustaining haptic contact for some time. Such acts do not involve active movements such as tapping or stroking, but are organized as prolonged holding/haptic contact, initiated by the adult (Hall, 1963: 251). 
The family and educational settings in the empirical scope of the present study are complex social contexts where adults are involved in multifaceted tasks that include children's socialization (developing their behavioral/social competencies and knowledge) and accomplishment of daily tasks, while preserving the social ambience. The institutional organization of parenting and classroom work may involve adults' high entitlement to control children's actions, including their use of control touch in the practical management of everyday tasks. While sustained control touches were found in both settings, they were more recurrently used in classrooms (28 cases) than in families (4 cases). This distribution could be linked to the particular institutional nature of educational settings, which involve a large number of participants and multiple concurrent activities, and teachers' institutional obligations to manage children's conduct in order to create the necessary conditions for a successful learning environment. A common sociocultural characteristic of these settings in Sweden is that corporal punishment and physically violent actions against children have been forbidden by law since the 1950s (in the schools) and 1970s (in families). However, in contrast to the US and Great Britain (Piper \& Smith, 2003), non-violent touch in educational settings has not been an issue for public debates and restrictions.

\subsection{Methodological approach}

In the present article, a selection of 5 interactional episodes, covering key variations in the phenomenon, is discussed. The present study deploys a multimodal interactional approach, examining the organization of situated activities (Goodwin, 2000; Depperman, 2013). This approach allows examination of multiple characteristics in the situated use of touch: type, location, approximate duration, function, and interactional context. Such methods, however, do not give access to the individual's introspective experience of touch. The analytical focus is therefore on touch behavior and what can be identified as the interactional uptake of touch, 
displayed through the publicly visible actions of the participants. Touch can be accepted or rejected, such as when a recipient complies, or moves away, grimaces, or withdraws from corporeal contact.

\section{Findings}

The interactional analysis shows that, in educational and family interactions, temporally extended and sustained forms of touch are employed by adults to manage and monitor children's participation in ongoing activities, usually calling for 'appropriate' displays of attention to particular activities. Sustained touch puts evolving limits on the child's postural orientation and movements by establishing a sensorial, haptic contact, and is instrumental in arranging the child's bodily positioning into a particular participation framework. The adult uses touch to monitor, choreograph, and modulate the recipient's (child's) involvement within a situation, usually 'repairing' prior participation between the adult and child (Goodwin \& Goodwin, 2004: 229). In the following, I will discuss how adults use sustained touch to: 1) request and secure the child's attentive participation; 2) exclude the recipient from the participation framework.

\subsection{Sustained touch: Setting limits to the child's embodied actions}

Sustained touch is usually used in socializing and disciplining encounters where it accompanies adults' attempts at (re-) aligning the 'operative framework of mutual attention' (Goodwin \& Cekaite, 2013) by indicating the touch-giver's bodily co-presence and putting limits on and restricting the child's motility. Adults use temporally extended touch to enforce and sustain the child's focused 'situational involvement' by 'fixating' the recipient's (child's) body (in one place). They establish a temporally extended display of 'attentive listening' or redirect the touch-recipient's attention when they try to recruit the child's attention to an 
extended explanatory or disciplining talk activity, or explain a concept to him/her (Fleck \& Chavajay, 2009).

In this excerpt from family interactions, 5-year-old Emil is sitting on the kitchen table. He starts playfully drumming on Mother's hands and when his 'drumming' gets stronger, Mother sanctions him and uses haptic control (lines 2-5). Upon Emil’s noncompliance, she takes hold of and stops the boy's hand, places her hands on the his body trunk, establishing a haptic control formation (lines 4-5).

\section{Ex. 1}

1 Emil: $\quad$ Men mamma. Du är min trumma. But mom. You're my drums.

2 Mother: A men du får inte trumma så hårt i så fall. Well but then you' can't drum so hard.

3 Emil: ((drums hard))

4 Mother: \# Emil! ((gets hold of his drumming hand))

5 Mother: \#*Du (.) Ska jag hjälpa dig att borsta tänderna?

Listen (.) Should I help you brush your teeth? * puts her hands on Emil's arms ->

6 Mother: Eller så kan du fixa det själv. Så kan duOr you can do it yourself. You can-

7 Emil: ((blows air towards Mom))

8 Mother: Så kan du borsta tänderna. You can brush your teeth.

9 Emil: ((blows air))

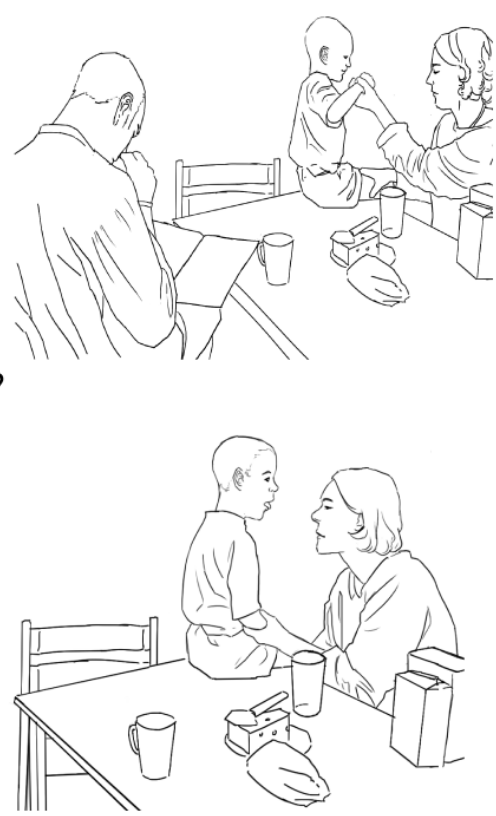


10 Mother: Ne:j Emil! NE:J sluta (.) vid matbordet!

No: Emil! NO: stop it (.) at the dinner table. ((turns away))

11 Emil: ((blows air))

12 Mother: Sluta!

\section{Stop it!}

13 Emil: Ne:j.

No:. ((blows air))

14 Mother: \#*Ne:j. Nu får du gå ne:d.

No:. You have to go do:wn now. ((moves him down from table))

15 Emil: Ne:j.

No:.

16 Mother: \# *Nej men det är äckligt. Jag vill inte att du gör såhär.

No it's disgusting. I don't want you to do this.

*holds hands around Emil's body trunk ->>

17 Emil:

Det här är inte äckligt!

It's not disgusting!

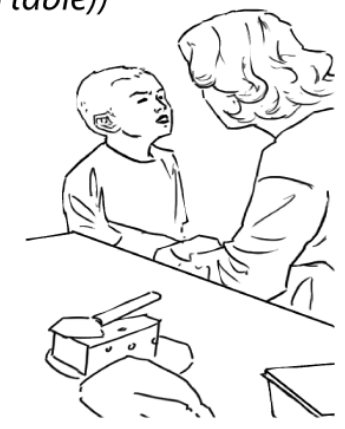

Mother summons his attention and introduces a new course of action, asking whether he needs her help to brush his teeth (line 5). She establishes a haptic formation, where she and Emil are positioned in a corporeally assembled F-formation, and uses touch in a firm manner, which seems to be a response to his resistance. Mother gazes at Emil, and through her touch, she indicates the limits of the child's contingent bodily actions. Physically holding hands around the child's trunk, she indicates her bodily co-presence (lines 5-13). She monitors an embodied participation framework, trying to solicit and sustain a single heightened framework of attention (toward her questions) as she solicits a response from Emil.

As noted by Goffman (1963), situational requirements are of a moral character, and the individual is obliged to maintain them. Here, 'actions demonstrating forms of involvement performed by parties within evolving structures of talk and embodied actions' (Goodwin \& Goodwin 2004: 222) indicate the child's digression and so-called emigration of the self (which can occur 'without leaving one’s physical position', Goffman, 1963: 194) from the adult-defined situation, as Emil does not respond to mother's question (line 9). He starts blowing air on Mother, who urges him to stop (lines 10-16). Her sustained touch behavior is 
then transformed into yet another type of control touch (a physically strong act) terminating his noncompliant actions, when she lifts Emil down from the table (line 14). (A somewhat different lamination of action is configured here, as Mother coordinates it with a verbal directive 'nu kommer du ned' 'you're coming down now' as she pulls Emil down). Mother continues the embodied disciplining, holding her hands around Emil's body trunk (lines 1617) and assembling a haptic facing formation. In a similar manner to lines $5-13$, temporally extended touch is used to arrange an operative framework of heightened attention by establishing a particular spatial-bodily arrangement and enforcing a common orientational perspective.

\subsubsection{The prospective and retrospective functions of sustained control touch}

A significant characteristic in the use of sustained touch as an interactional attentionorganizing resource (de León, 2012) is its projective and retrospective orientation toward the child's activity involvement. Sustained touch can be deployed as a normative response to the recipient's (child's) ‘digression from the situation,' such as inadequate participation, lack of attention, or withdrawal. Prospectively, sustained touch organizes the participation framework and solicits the recipient's bodily involvement and display of 'focused attention,' i.e., cooperative and attentive participation and listening (in commonly occurring F-formation). Temporally, it is coordinated with the speaker's initiation of so-called interactionally 'big packages’ (Sacks, 1992: 235), and attempts to recruit the child recipient's attention and touch are sustained through an extended explanatory or disciplining talk activity.

In Ex. 2, temporally extended touch is initiated during an instructional exchange in which Jasmin, the student, shows her reluctance to engage in collaborative work on exercises. Immediately before this, Jasmin had refused to do classroom work several times and even attempted to leave the classroom. As this episode starts, not only her talk but also body 
posture and gaze signal her detachment from the activity in progress. Jasmin turns away from the teacher and the exercise book, sitting with a sullen look on her face, exhibiting her lack of attentive involvement within the situation (line 1).

Ex. 2

1 Jasmin: \# A:hhh jag vill inte gö:ra dom. A:hhh I don't wanna do: them.

2 Teacher: Men du. \#*Ved du vad? (0.3)

But listen. You know what? (0.3)

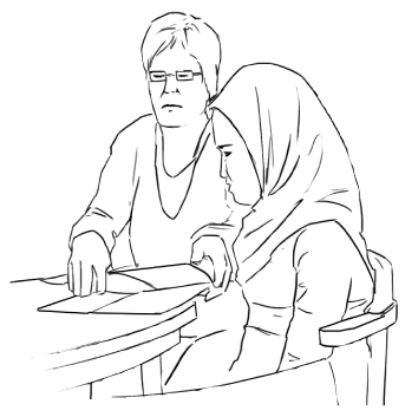

* takes hold of Jasmin's hand -->

3

Om din mamma inte vill laga mat, kan hon strunta i det då?

If your mom doesn't want to cook, can she ignore it?

4 Jasmin: A

Yeah.

5 Teacher: Kan hon det?

Can she?

6 Jasmin: Jag kan laga.

I can cook.

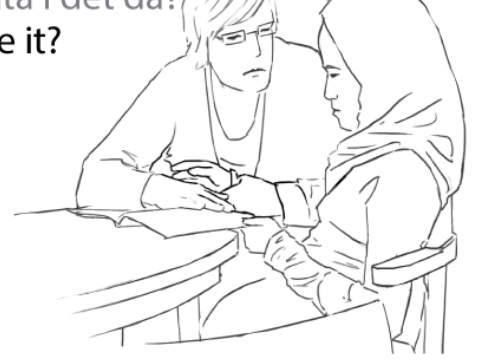


7 Teacher: Kan jag strunta i att åka till jobbet om jag inte vill det? Can I just not go to work if I don't want to?

8 Jasmin: \#Ne:j=

No:=

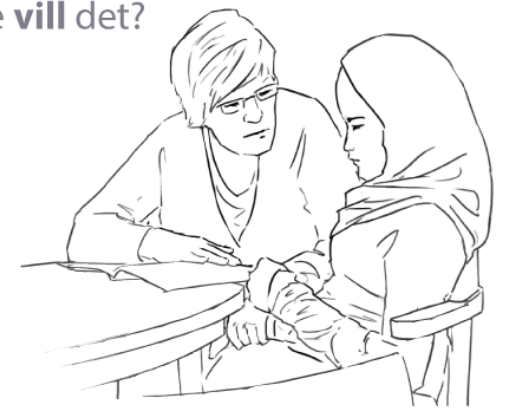

9 Teacher: =Nej. Man kan inte göra det vet du. *\#Det är därför det är så viktigt ( ).

$=$ No. You can't do that, you know. That' why it's so important to ( ). -->* ((withdraws her hand from Jasmin's, takes notebook))

10 Jasmin: Jag har gjort det här. I've done that. ((points at an exercise in the book))

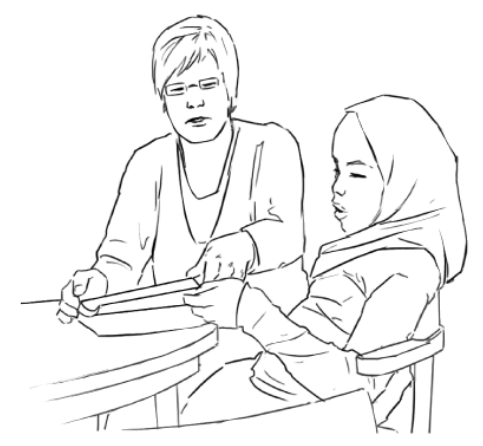

In response to the child's apparent inattentiveness and unwillingness to work on a classroom task, the teacher initiates a socializing encounter, using display questions (known-answer questions that test students' knowledge and put that knowledge on public display O’Cafee et al, 2007) (lines 3; 7). As she shifts the activity frame, summoning Jasmin's attention and introducing the noteworthiness of what is to come next, she gazes at Jasmin and puts her hand on the child's hand, thus establishing a haptic F-formation (lines 2-3). The teacher sustains haptic control for a considerable period of time, during which the child answers the teacher's display questions. As the adult touches her lightly on the hand, Jasmin verbally disaffiliates from the teacher's socializing agenda. For instance, she resists the teacher's attempt to link her work to her mother's cooking ('I can cook', line 6). When the teacher relates Jasmine’s work to the teacher's own work ('Can I just not come to work if I don’t want to'), she gets an aligning response (line 8), but then another disaligning response ('I've done that '(exercise)', line 10). In these utterances, the teacher frames Jasmin's worksheet activity and schoolwork 
as obligation and relates it to her mother's cooking in the home (gender socialization) and the teacher's coming to school. The teacher's sustained touch is withdrawn when the teacher moves on to the closure of the socializing encounter, with a concluding statement that foregrounds the child's responsibilities as student ('därför är det så viktigt' 'that's why it's so important', and opens the student's book (marking a transition to the classroom task, line 9).

\subsubsection{Haptic co-presence, control, and light forms of touch}

Sustained physical contact can take on different shapes and durations, and it is laminated with talk, gaze, and various spatial-bodily arrangements, gaining its communicative meaning in configuration with other semiotic means (Ex.1-2). Commonly, physically rather light touch such as holding a hand is efficient in organizing an operative framework for participation. Touch becomes a corporeal anchor signaling the adult's co-presence, i.e., monitoring and control.

In Ex. 3, the teacher and a group of boys are engaged in a heated discussion about a conflict during soccer. Hamid, a key participant in the conflict, tries to leave the scene but the teacher calls him back. As the boy approaches, she shepherds him and engages him in a haptic C-formation (control formation), placing her hands on Hamid's shoulders (Cekaite, 2010) and positioning him so that he is facing the other boys (lines 2-4).

Ex. 3 
1 Hadi: Och då var det så att ha:n vad hetter det-

And then it was like this that he: what's he called-

2 Teacher: = Kom ska du lyssna.\#

Come here and listen. ((to Hamid))

3 Hamid: ((comes to teacher))

4 Teacher: shepherds him *puts hands on his shoulders, positions him to face the boys -->>

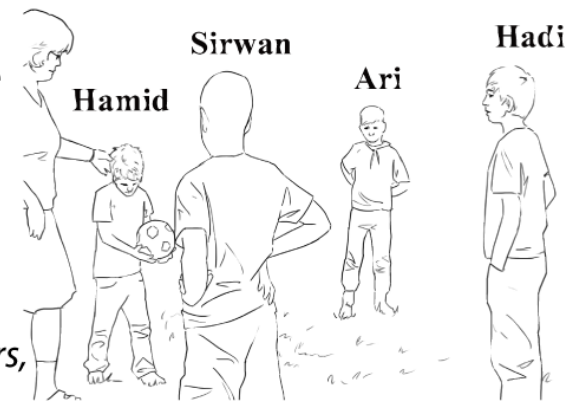

5 Teacher: \#A.

Yeah. ((to Hadi))

6 Hadi: A. Då sa Sirwan 'nej jag vill inte va med längre' Yeah. Then Sirwan said 'no I don't want to play för att Hamid sa att han sa ( ). any more' because Hamid said that he said ( ). ((long explanation, discussion about soccer conflict))

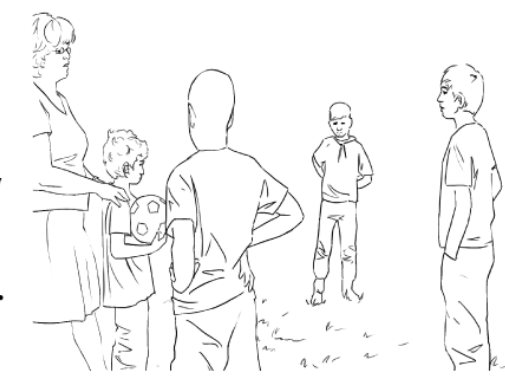

8 Teacher: \#Men är det (.) försökte (.) om om om man får en tackling.

But if it is (.) tried (.) if if if you get rigged.

9 Teacher: Men får man ge igen i en fotbollsmatch?

But are you allowed to fight back during a soccer game? ((to the group of boys))

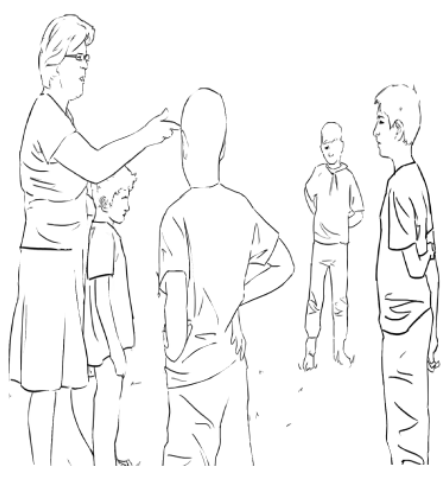

10

((soccer discussion continues,

Sirwan and Hamid try to kick the ball, teacher keeps her hands on Hamid's shoulders))
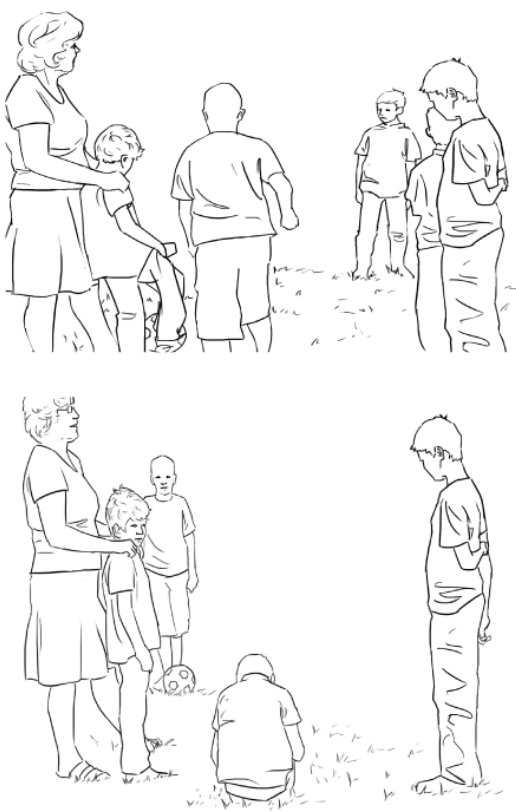
The teacher readjusts Hamid's body position and his postural orientation. She positions him to face the other boys, the key participants in the soccer conflict, and establishes the children's facing formation (lines 2-4). The participants are engaged in a conflict-resolution-seeking encounter that constitutes a temporally extended conversational unit. Throughout the 4minute period, until the school bell rings, Hamid is physically positioned as an attentive participant (lines 2-4). The teacher's light touch is sustained during the morally laden discussion: she, for instance, gestures, holding only one hand on Hamid’s shoulder (lines 8-9). Despite its light form, the adult's sustained touch puts constraints on the child's embodied actions and movements, and Hamid's body position and orientation are fixed and stationary. His competing focus of interest (kicking the ball) is monitored and corrected by the teacher, who, through her haptic control (she keeps her hands positioned on Hamid's shoulders) does not allow his bodily and attentional withdrawal from the encounter (lines 10-11). Throughout the encounter, the participants exhibit emerging mutual adjustments that involve the teacher's continuous touch, which perceptually signals her bodily co-presence and control of Hamid's body movements.

Such control aspects of touch can be linked to the immediacy and public availability of coperception of haptic involvement. The immediacy of co-perception of two interacting bodies provides for continuous interpretations, adjustments, and calibration of (corporeal) acts vis-àvis each other. Temporally extended touch in focus does not provide full physical control of the child's actions or body posture, however, it does indicate the adult's co-presence somatically/perceptually (lines 2-11). Through the contingent actualization of sensory experiences, the adult monitors and controls the recipient's bodily accountability for cooperative participation in a joint encounter. Here (Ex. 3), haptic control is sustained as a predominantly collaborative achievement and involves the child's compliant, non-resistant uptake of touch. The perceptual immediacy of haptic response can be significant in securing 
the child's compliance: Because of the bi-directional characteristics of touch, non-compliant bodily response/action (e.g., the child's refusal to be touched, shown, for instance, by the withdrawal of his/her hand) is potentially immediately corporeally noticeable to the adult. Physically light touch can thereby provide a sufficient resource to prevent the child from producing bodily displays of noncompliance, i.e., withdrawing or leaving the situation (e.g., walking away).

\section{2 Sustained control touch in multi-activity situations}

Temporally extended touch is also used to sustain a particular embodied participation framework by excluding the recipient of touch from participation in the ongoing encounter (between the 'giver' of touch and another participant). Such uses occur in multi-activity situations (Haddington et al., 2014) where, in the midst of competing activities and engagements, the adult manages several complex participation frameworks and participants. In contrast to Excerpts 1-3 above, where the participants are engaged in a joint encounter and where adults are calibrating the child's attention toward a single focus of attention, the speaker/adult can use sustained touch to organize multiple children’s activity engagements.

\subsubsection{Using touch to exclude someone from a participation framework}

The participation framework is not established once for all, but is continuously being monitored and negotiated. With more than two participants, there may be persons who are physically present in the situation (Goffman, 1971) but who, in different ways, are not ratified as participants. Sustained touch, together with other semiotic resources, can be used to set up an exclusive participation framework and, by using sustained touch, the adult can manage the selection of participants, indicate which child he/she wants to interact with at any single moment or to exclude from the participation framework. 
In Ex. 4, during an extended and intense dyadic disciplining interchange between the teacher and Hamid, John, who is sitting at the same desk, tries to join the encounter. The teacher uses various types of embodied actions to establish and control the participation framework by excluding John. The teacher's upgraded disciplining is occasioned by Hamid's noncompliance with the teacher's directive. She tells him to put the scissors away in a safe place so that he will not accidentally harm his classmates. However, Hamid does not comply and instead, he uses the scissors, pretending to cut other children's hair. The teacher responds with an upgraded moral admonishment, attempting to recruit Hamid to show his understanding of the seriousness of his transgression (line 1).

Ex. 4.

1 Teacher: Om saxen kommer i nåns öga! Vad tror du händer då?

If scissors will get into somebody's eyes! What do you think will happen then?

2 John: Man blir [död. They die.

3 Hamid: [Man blir död. They die.

4 Teacher: \#*approaching gesture toward John->

5 John: ((moves away from teacher's hand))

6 Teacher: *Nej. Man dör inte. Vad händer då? No. you don't. What happens?

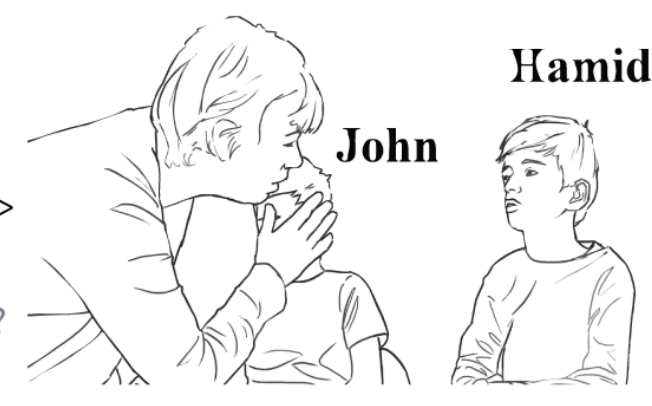


((talk omitted))

10 Teacher: Du (.) Hamid!

Listen (.) Hamid!

11 John: ( ) ((moves towards teacher $))$

12 Teacher: \#* puts her hand on John's arm ->

13 John: ((moves away from teacher))

14 Teacher: Då ska du inte leka med saxar! Then you shouldn't play with scissors! ((to Hamid))

15 Hamid: \#OK. ((exaggerated nods))

16 Teacher: Dom har vi när vi klipper. We use them for cutting.

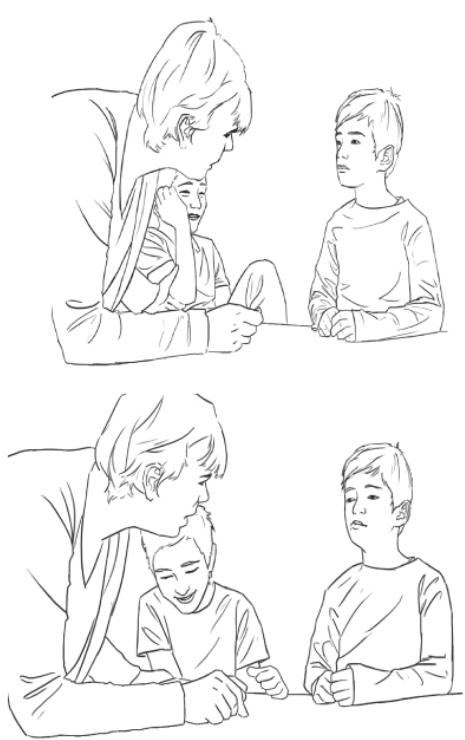

17 Teacher: Du blir ledsen om nån gör dumma saker mot dig.

You get upset when others do stupid things to you.

18 Hamid: A.

Yeah. ((covers his face 'mock crying'))

19 Teacher: \#**Tror du att dom blir**ledsna när du gör dumma saker.

$-{ }^{*}{ }^{*}$ Do you think they'll get * *upset when you do stupid things?

*removes Hamid's hand from his face ${ }^{*}$ holds his hand on desk -->>
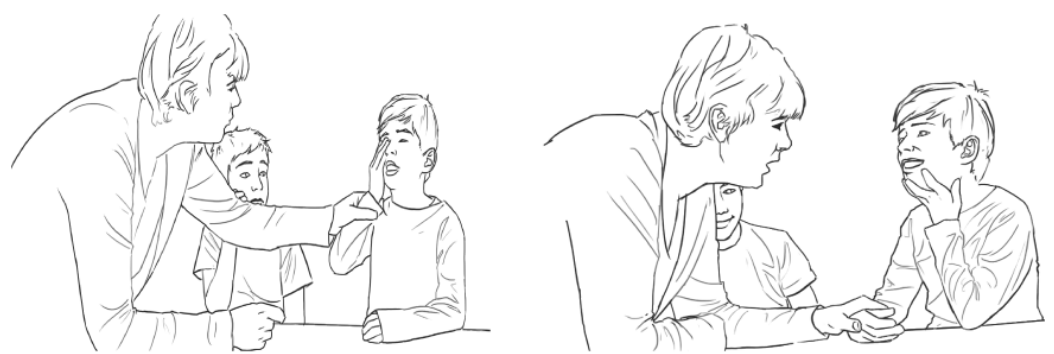

20 Hamid: ((nods))

21 Teacher: Men du (.) Hamid. Då behöver du tänka också.

But listen (.) Hamid. Then you need to think too.

The disciplining encounter targets only Hamid, but his responses are non-compliant and the teacher uses various resources to solicit his attentive and adequate participation: They are arranged in an intense facing formation within a close bodily configuration. When John attempts to join the encounter (line 2), the teacher moves her hand/palm toward him, closing into his bodily space, and John moves away from the potential haptic contact with the teacher, terminating his conversational participation as well (lines 4-5). When he tries to join the encounter again (line 11), the teacher touches him and puts her hand on his arm, while she 
continues talking to Hamid (line 12). She does not withdraw from or interrupt the disciplining encounter, preserving an intense facing formation with Hamid. Upon the teacher's touch, John stops his conversational attempt. We can see the emergent and dynamic character of sustained haptic control: The teacher rearranges her haptic act according to John's bodily movements and 'fixates' John's arm and body posture in a particular position for a considerable time, preventing him from entering into the dyadic participation framework between her and Hamid (lines 12- 19).

The teacher withdraws her hand from John only when she uses a 'corrective' touch on Hamid as she removes his hand from his laughing face (line 19). She coordinates this haptic action with an admonishment ('tycker du' 'do you think') that indexes the purpose of her haptic intervention (cf. Cekaite, 2015). Such 'corrective' touch formats are responsive to the immediate situational concerns by terminating the child's ongoing embodied action - an action that violates some normative concerns. Sustained touch in lines 12-19 and 19-21, on the other hand, constitutes a method that allows realization of the adult's multiple concurrent involvements directed at several individuals. The teacher sustains the touch contact, keeping her hand on Hamid's during the entire disciplining event (two more minutes), using it as a bidirectional interactional resource for co-perception: signaling the embodied control and taking in the child's embodied responses.

\subsubsection{Touch as a prosthetic resource signaling attentional readiness and co-presence}

Multiple uses of sustained touch are further demonstrated in multi-activity situations where the adult uses a haptic act as a prosthetic resource to project her/his postponed attention (for the recipient of touch). The adult maintains the main talk-based commitment while using extended temporal contact to put the second course of action (the interaction with the recipient of touch) on hold. Simultaneously, sustained touch excludes the child/recipient of 
touch from participating in the encounter. The 'giver' of touch indicates his/her main engagement through bodily posture, orientation, and talk engagement. In contrast to cases where sustained touch is used to solicit the recipient's attentive participation, coordinated with the adult establishing a facing formation toward the recipient of touch (Ex. 1; 3), here sustained touch is combined with the adult's bodily orientation away from the recipient of touch.

In Ex. 5, a student named Fahmo calls out to tell the teacher that she has finished the exercises (line 1). The teacher approaches Fahmo, indicating her commitment to assisting her, but then re-orients toward another student, Lisa (lines 2; 4).

Ex. 5.

1 Fahmo: Fröke:n! Kla:r!

Teache:r! Fi:nished!

2 Teacher: \#((walks towards Fahmo))

3 Fahmo: Alla bilderna!

All the pictures!

4 Teacher: *puts hand on Fahmo's shoulder, turns to Lisa->

5 Teacher: Lisa? \# (Du kan ta dem) [för sig (.) att bygga med.

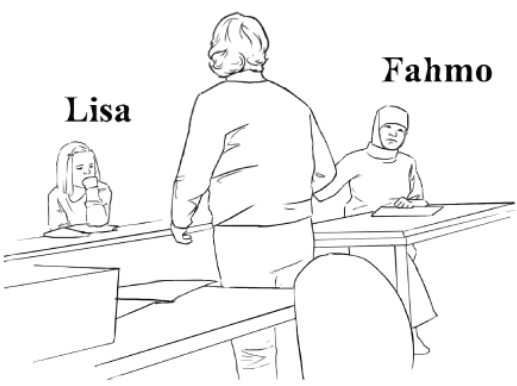

Lisa? (You can use these) separately (.) to build with.

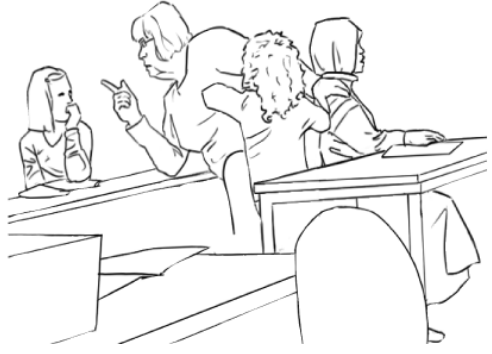


6 Fahmo: \#[Alla kla-ar!

[All fi-nished! ((taps teacher's hand))

7 Lisa: ( )

8 Teacher: Mh. ((to Lisa))

9 Teacher: ((moves her hand from Fahmo's shoulder, turns to Fahmo))

10 Fahmo: Kla:r!

11 Teacher: \#looks at Fahmo's notebook->>

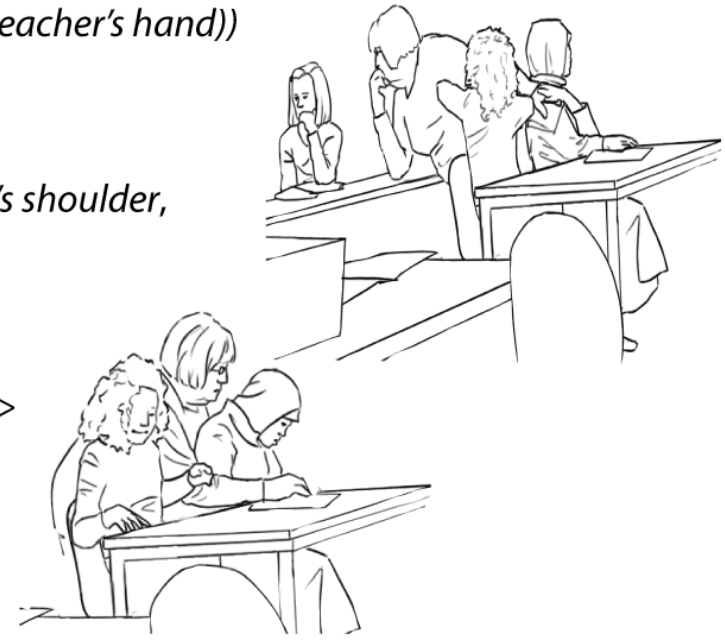

This commitment is put on hold when the teacher turns toward and engages in talk with another student, Lisa (lines 4-5). Here, the adult's multiple engagements are indexed by her temporally sustained touch (hand on the child's shoulder) (lines 4-9). The teacher uses touch as a sensory resource, signaling her embodied co-presence, continuous bodily control, thereby projecting her future availability.

Importantly, despite Fahmo's attempts to re-gain the teacher's attention (she taps the teacher's hand, line 6), the teacher sustains her instructional activity with Lisa (lines 7-8). The haptic format and the bodily-postural configuration (the teacher's facing-formation toward Lisa) are resources that sustain her current main (talk-based) participation framework, while simultaneously indicating her co-presence to Fahmo, constraining the child's actions, and implicating her prospective engagement. The teacher withdraws her touch when she disengages from the interactional exchange with Lisa and re-orients toward Fahmo (lines 9; 11).

\section{Concluding discussion}

Control touch practices are important in understanding the embodied facets of adult-child social interactions, and the interactional instantiation and negotiation of coercion and bodily 
integrity. Particular forms of control touch are clearly interactionally organized, and they contribute to the dynamic structuring of participation and attention in social interaction. By using sustained touch, the participants establish a corporeal perceptual field that affords their emerging, contingent adjustments of verbal and embodied actions: Haptic actions create bodily contact spaces for the co-perception of bodily movements, e.g., kinesthetic experiences, and the haptic monitoring of mutual perceptions.

As suggested by Goffman (1963), situational co-presence and cooperative stance are regulated by (implicit) expectations that have the character of moral obligations. The present study contributes to these theoretical observations by providing a detailed analysis of sustained control touch as it is used to manage and choreograph the recipients' (children's) participation, focused attention and situational co-presence. Adults' touch is temporally finely tuned to the mobilization and use of linguistic resources and is used to arrange, and actively maintain, embodied participation frameworks, soliciting a shared orientational perspective. There is an interplay of visual, haptic, and vocal resources, configured in response to the child's 'digressions from the situation,' which is characterized by unwilling embodied stance, bodily or attentional withdrawal. 'Eye-to-eye ecological huddle' tends to accompany sustained touch, and is carefully maintained, maximizing the opportunity for participants to monitor each other's actions (Goffman, 1963: 191) (Ex. 1; 3). Touch is also coordinated with the built environment, as demonstrated in the different spatial configurations of the participants' bodies, such as when the teachers bend over towards students who are seated in their desks (Ex. 2; 3; 5), position the child to face the group of students (Ex.3), or when the parent lifts the child from the table (Ex.1).

Temporally extended touches can be seen as a resource for restricting the motility of the recipient/child. Metaphorically speaking, they 'freeze' the recipient's bodily position. Touch practices thereby actualize the relevance of the dialectics of movement and stability, i.e., 
body-in-motion, in the organization of social encounters. Retrospectively, sustained touch orients to the child recipient's inattentiveness and inappropriate participation, i.e., 'reduced situational co-presence' (Goffman, 1963: 198). Prospectively, it solicits and monitors the child's cooperative and attentive participation in activities that constitute a state of talk: extended instructions, disciplining, or other kinds of socializing practices (Ex. 2-3).

In multi-tasking situations, sustained touch works to manage the multiple overlapping participation frameworks. The adult, engaged in a talk-based activity, constrains the touch recipient's conversational contribution, or puts it on hold, using sustained touch as a prosthetic resource to signal her/his prospective attention. Such interactional organization, timing and duration of touch reveal the relevance of the child's bodily participation, operationalized as adequate embodied displays of cooperation and attention.

Understanding the dynamics of how sustained touch allows achievement of the child's bodily compliance can provide some insights into the situated character of the adults' and children's bodily integrity, physical coercion and social control. Although sustained touch in focus usually does not involve considerable physical force, it nevertheless escalates the balance of bodily integrity: The adult enters and manipulates the child's embodied/kinesthetic space and, through an enforced haptic contact, puts limits and constraints on the child's body movements. Even light touch gains moral valence, becoming an effective resource for social control. Because of the immediate and bi-directional character of touch, the recipient's bodily uncooperativeness and resistance - for instance, simple withdrawal - are immediately made public, i.e., experienced visually and haptically by the adult, thus potentially preventing the child from manifesting bodily non-compliance. This does not necessarily prevent the child from displaying disaffiliation verbally (Ex. 1; 3).

Joint attention and participation are prerogatives for joint social action, requiring cooperation and willingness, but the underlying cooperative stance cannot be taken for 
granted (Cekaite, 2012). Institutions - families and schools - engage in various practices, including sustained touch, to socialize and enforce children's displays of cooperation and attention (Ex.1-5). Importantly, as demonstrated, attention is not only the aim, but also a precondition for socialization, and normative practices for organizing attention stretch beyond infancy and the preschool years (cf. de León, 1998; Goodwin, 2006; Burdelski, 2010; Moore, 2013). In all, the interactional analysis of interpersonal touch shows how the situational conditions, social roles and relations inform and shape body behavior. Interpersonal touch thereby constitutes a fruitful focus when investigating the multiple facets of the pragmatics of social interaction and, by revealing some of the corporeal orders and body techniques of institutions, it makes an empirically grounded contribution to sociological and anthropological understandings of sociality.

\section{Notes}

${ }^{1}$ The family data are part of a large-scale video ethnography (CELF) documenting family life in the U.S., Italy and Sweden (project leaders Elinor Ochs (USA) and Karin Aronsson (Sweden), financial support from A.P. Sloan Foundation). The data collection in families and in the primary school has followed the Swedish Research Council's ethical guidelines for collecting and handling data. Names, images and other identifiers have been anonymized.

${ }^{2} 28$ cases of sustained control touch from educational settings and 4 from families are within the scope of the analysis.

\section{Transcript conventions}

Talk has been transcribed using conventions developed by G. Jefferson. Original talk in Swedish is provided in grey color and indicative translation in black. Multimodal features have been transcribed according to conventions developed by Lorenza Mondada (2011). 


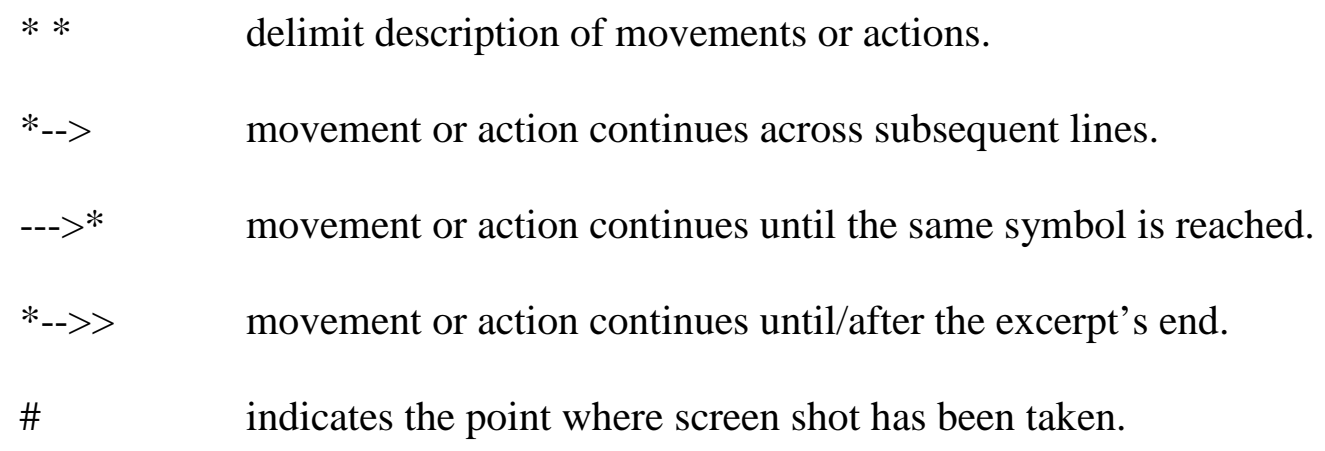

\section{References}

Brown, Penelope 2012. The cultural organization of attention. In: Duranti, A., Ochs, E. \& Schieffelin, B. (Eds), The handbook of language socialization. Malden: Wiley-Blackwell, pp. 23-28.

Cekaite, Asta, 2010. Shepherding the child: Embodied directive sequences in parent-child interactions. Text \& Talk, 30/1, 1-25.

Cekaite, Asta, 2012. Affective stances in teacher-novice student interactions: Language, embodiment, Language in Society, 41, 641-670

Cekaite, Asta, 2015. Coordination of talk and touch in adult-child directives. Touch and social control. Research on Language and Social Interaction, 48, 152-175.

Csordas, Thomas 2008. Intersubjectivity and intercorporeality. Subjectivity 22, 110-121.

Broth, Mathias \& Mondada, Lorenza 2013. Walking away: The coordinated achievement of activity closings in mobile interaction. Journal of Pragmatics 47, 41-58.

Burdelski, Matthew 2010. Socializing politeness routines: Action, other-orientation, and embodiment in a Japanese preschool. Journal of Pragmatics 42, 1606-1621.

de León, Lourdes 1998. The emergent participant: Interactive patterns in the socialization of Tzoltzil (Mayan) infants. Journal of Linguistic Anthropology 8, 131-161. 
de León, Lourdes 2012. Language socialization and multiparty participation frameworks. In: Duranti, A., Ochs, E. \& Schieffelin, B. (Eds), The handbook of language socialization. Malden: Wiley-Blackwell, pp. 81-112.

Depperman, Arnulf 2013. Conversation analytic studies of social interaction. Journal of Pragmatics 46, 1-7.

Fleck, Bethany \& Chavajay, Pablo 2009. Physical interactions involving pre-schoolers and kindergarteners in a childcare center. Early Childhood Research Quarterly 24, 46-54.

Goffman, Ervin 1963. Behaviour in public places: Notes on the social organization of gathering. New York: Free Press.

Goffman, Ervin 1971. Relations in public: Micro-studies of the public order. New York: Harper and Row.

Goodwin, Charles 2000. Action and embodiment within situated human interaction. Journal of Pragmatics 32, 1489 - 1522.

Goodwin, Charles 2007. Participation, stance and affect in the organization of activities. Discourse in Society 18, 53-73.

Goodwin, Charles \& Goodwin, Marjorie 2004. Participation. In: Duranti, A. (Eds.) A companion to linguistic anthropology. Malden: Blackwell, pp. 222-244.

Goodwin, Marjorie 2006. Participation, affect, and trajectory in family directive/response sequences. Text and Talk 26, 515-544.

Goodwin, Marjorie In press. Haptic sociality. The embodied interactive construction of intimacy through touch. In: Meyer, C., Streeck, J. \& Scott Jordan, J. (Eds.), Intercorporeality: Beyond the body. Oxford: Oxford University Press.

Goodwin, Marjorie Harness \& Cekaite, Asta, 2013. Calibration in directive/response sequences in family interactions. Journal of Pragmatics, 46, 122-138. 
Haddington, Penty, Keisanen, Tiina, Mondada, Lorenza \& Maurice Neville 2014. Multiactivity in social interaction. Amsterdam: Benjamins.

Hall, Edward 1963. A system for the notation of proxemics behaviour. American Anthropologist 65, $1003-1026$.

Hertenstein, Matthew \& Weiss, Sandra 2011. The handbook of touch. Springer. Jones, Stanley \& Yarborough, Elaine 1985. A naturalistic study of the meanings of touch. Communication Monographs 52, 19-56.

Kendon, Adam 1990. Spatial organization in social encounters. The F-formation system. In: Kendon, A. (Ed.), Conducting interaction. Patterns of behavior in focused encounters. Cambridge: Cambridge University Press, pp. 209-230.

Kääntä, Laila \& Marsh-Piirainen, Arja 2013. Manual guiding in peer group interaction: A resource for organizing a practical classroom task. Research on Language and Social Interaction 46, 322-343.

Linell, Per 2009. Rethinking language, mind and world dialogically. Aspects to human sensemaking. Charlotte, North Carolina: Information Age Publishing.

Mauss, Marcel 1973 [1935]. Techniques of the body. Economy and Society 2, 70-88.

McIlvenny, Paul 2009. Communicating a 'Time-Out' in parent-child conflict. Journal of Pragmatics 41, 2017-2032.

Merlau-Ponty, Maurice 1962. Phenomenology of perception. Transl. C. Smith. London: Routledge \& Kegan Paul.

Mondada, Lorenza 2009. Emergent focused interactions in public places. Journal of Pragmatics 41 (10), 1977-1997. 
Mondada, Lorenza 2011. The organization of concurrent courses of action in surgical demonstrations. In: Streeck, J., Goodwin, C. \& LeBaron, C. (Eds.), Multimodality in communication. Cambridge: Cambridge University Press, pp. 207-226.

Montagu, Ashley 1971. Touching: The human significance of the skin. Columbia: Columbia University Press.

Moore, Ekaterina 2013. “Children are all looking at you”: Child socialization, directive trajectories and affective stance in a Russian preschool. Pragmatics in Society 4, 317-344.

Ochs, Elinor, Solomon, Olga, \& Sterponi, Laura 2005. Limitations and transformations of habitus in child-directed communication. Discourse Studies 7 (4-5), 547-583.

O'Keeffe, Anne, McCarthy, Michael and Carter, Ronald 2007. From Corpus to Classroom: Language Use and Language Teaching. Cambridge University Press.

Piper, Heather \& Smith, Hannah 2003. 'Touch’ in educational and child care settings: dilemmas and responses. British Educational Research Journal 29, 876-894.

Sacks, Harvey 1992. Lectures on conversation (Vol. 2.). Oxford: Blackwell.

Sheets-Johnstone, Maxine. 2012. The primacy of movement. Amsterdam: Benjamins. Streeck, Jurgen, Goodwin, Charles \& Courtis LeBaron 2011. Embodied interaction in the material world: An introduction. In: Streeck, J., Goodwin, C. \& LeBaron, C. (Eds.), Multimodality in communication. Cambridge: Cambridge University Press, pp. 1-28.

Tomasello, Michael \& Ferrar, Michael 1986. Joint attention and early language. Child Development 57, 1454-1463.

Tulbert, Eve \& Goodwin, Marjorie 2011. Choreographies of attention. Multimodality in a routine activity. In: Streeck, J., Goodwin, C. \& LeBaron, C. (Eds.), 
Multimodality in communication. Cambridge: Cambridge University Press, pp. 79-92.

Turner, Bryan 2008. The body \& society ( $3^{\text {rd }}$ ed.). London: Sage. 